\title{
Review
}

Author(s): G. G.

Review by: G. G.

Source: The Geographical Journal, Vol. 22, No. 4 (Oct., 1903), pp. 451-452

Published by: geographicalj

Stable URL: http://www.jstor.org/stable/1775464

Accessed: 26-06-2016 11:50 UTC

Your use of the JSTOR archive indicates your acceptance of the Terms \& Conditions of Use, available at

http://about.jstor.org/terms

JSTOR is a not-for-profit service that helps scholars, researchers, and students discover, use, and build upon a wide range of content in a trusted digital archive. We use information technology and tools to increase productivity and facilitate new forms of scholarship. For more information about JSTOR, please contact support@jstor.org.

The Royal Geographical Society (with the Institute of British Geographers), Wiley are collaborating with JSTOR to digitize, preserve and extend access to The Geographical Journal 
ordinary unscientific public will find a most readable summary of these important investigations (which illustrate quite a new chapter in human history) in the book which has just been published.

T. H. H.

\section{India in Earty Maps.}

'La Cartografia antica dell' India.' By Francesco L. Pullé. Firenze, 1901. (In Studi Italiani di Filologia Indo-Iranica, Anno IV. vol. iv.) With an Atlas of Maps.

This is a study of high interest and value. It is divided into seven parts, in which the conceptions of India and its configuration are discussed, as entertained by the ancient Egyptians, Babylonians, Phœnicians, and Jews, by the Indians themselves, by the Greeks, by the Romans and Alexandrians, by the scholars of the 'Lower Empire,' by the Byzantines, and by the Arabs and Persians. Appendices are added on certain special authors or treatises and their account of Indiaon Pomponius Mela, on Pliny, on the Periplus of the Erythræan sea, on the Anonymous Geographer of Ravenna, and others. Among the larger maps in the 'Atlas' are facsimiles of the sixth-century world-scheme of Cosmas Indicopleustes, according to both the Florentine (Laurentian) and Vatican mant:scripts of the ninth and tenth centuries-of the same author's Mountain of the North, according to the Laurentian manuscript_of the Mappe-monde of Fra Mauro (14571459), etc. The text is also illustrated by thirty-seven smaller designs, largely modern reconstructions of ancient maps now lost; many of these, as is natural, follow the suggestions already given by that most stimulating inquirer, K. Miller of Stuttgart. Several clarified reproductions of mediæval maps, admirably executed, are also given, e.g. Cosmas, the Mappe-monde of Albi, Ibn Haukal, and Edrisi. The whole work is executed in a thorough and scholarly manner, and must be invaluable to every student of mediæval geography; the most recent work of continental scholars has been utilized, though the same cannot always be said of their English contemporaries. It is pleasant, however, to see so keen an appreciation of an essay of remarkable merit, too little known in England, Marinelli's 'La Geografia dei Padri della Chiesa,' long ago translated into German ('Die Erdkunde bei d. Kirchen-Vätern '), but still awaiting an English version. The treatment of India by Ptolemy, by the Periplus of the Erythræan sea, and by Cosmas, are handled by Sig. Pullé in a manner worthy of special praise. This is surely the first time that the world-scheme of the Alexandrian monk has ever been faithfully reproduced from the Vatican manuscript; it had already been photographed in 1897 from the Florentine copy, for reproduction in my own 'Dawn of Modern Geography,' vol i. p. 384.

C. Raymond Beazley.

\section{Persia.}

'The Persian Problem.' By H. J. Whigham. London: Isbister \& Co. 1903. Price 128. 6d.

Under the above title Mr. Whigham republishes, in an altered and amplified form, with maps and illustrations, a series of letters contributed by him in 19011902 from Persia to the Morning Post. 'The sub-title of the book, "An examination of the rival positions of Russia and Great Britain in Persia, with some account of the Persian Gulf and the Baghdad railway," is a sufficient indication of the object with which it is written. In some of the first twenty-two chapters Mr. Whigham deals mainly with various factors of the Persian problem, e.g. our position and prestige, past and present, in the Persian Gulf, Koweit, and the Baghdad railway, the attitude of his predecessors and of the present Sheykh of Muhammerah towards the Persian Government, the trade-routes from the Karun to the capital, 
and the equally important route viâ Baghdad and Kermanshah; iu others he sketches with a crisp touch the Arab pirate coast, the ruins of Mesopotamia, the sacred cities of Nejef and Kerbelá.

Mr. Whigham has the faculty of presenting in concise and well-chosen phrases a luminous résumé of any subject he deals with, whether that subject be a somewhat intricate question of local politics (e.g. in the case of Muskat) and its bearings on international questions, or the reconstruction of the Babylon of Nebuchadnezzar's day, as seen in the light of the most recent discoveries of Dr. Koldwey and his fellow-workers, or, again, the exploitation by a British capitalist of the oilwells of Kasr-i-Shirin.

In the closing six chapters Mr. Whigman sums up the relative positions, political and commercial, of Russia and Great Britain in Persia, and draws his conclusions. "The whole aim and object of our policy in Persia, first and last, should be railways. Russia may have all the political prestige she wants, so long as we control the railways from the Gulf to Tehran."

Since the publication of Lord Curzon's 'Persia' we have seen no work more helpful than Mr. Whigham's for a right understanding of the Persian question. Indeed, it is not too much to say that the volume forms a useful and almost indispensable supplement to that book, bringing it up to date on many points.

G. G.

\section{Formosa.}

'The Island of Formosa, Past and Present.' By James W. Davidson, F.R.G.s., Consul of the United States for Formosa. London: Macmillan \& Co. 1903.

Formosa must have been known to the Chinese at a period far beyond the ken of European historians; it is potentially one of the richest islands in the world, and the Dutch settlements upon it were founded so long ago as 1624. Yet, on the whole, the bibliography of the island is a remarkably limited one, and no really comprehensive work on it has been published in any language. In the volume under consideration Mr. Davidson seeks to remedy this omission, and, though it is very far from being complete, as the author himself would probably be the first to admit, it is, at all events, a step in the right direction, and for the large amount of really valuable information which he has got together, whether from his own experiences or those of others, the reader cannot be otherwise than grateful.

Of Mr. Davidson's thirty-one chapters no less than twenty-two are devoted to historical events. Chinese records furnish but few particulars as to the earlier periods, and in later times the Portuguese seem to have been content with naming the island only, for they made no settlements on it. It is with the advent of the Dutch that history really commences, and their occupation and final ejection by Koksinga are treated at some length, as is also the episode of the first Japanese expedition in 1874. The most important, and certainly the most interesting section of the historical part, however, is that descriptive of the Japanese campaign of 1895, which ended in the annexation of the island. Here we have an account of the affair at first hand, for Mr. Davidson was an eye-witness of the reign of terror which prevailed in Taipeh and Twatutia, and, indeed, took a sufficiently prominent part in the events of this most perilous and exciting time to earn him the decoration of the Imperial Order of the Rising Sun at the hands of the Emperor of Japan.

Leaving history for present-day conditions, Mr. Davidson passes to a consideration of the three great industries of the island-tea, camphor, and sugar, to each of which a chapter is allotted. Tea culture is principally confined to the 